\title{
Bioelectrical Impedance as a Diagnostic Factor in the Clinical Practice and Prognostic Factor for Survival in Cancer Patients: Prediction, Accuracy and Reliability
}

Muobarak J Tuorkey*

Biology Department, Division of Physiology and Medical Biochemistry, Faculty of Science, Damanhour University, Egypt

\begin{abstract}
Bioimpedance analysis could provide a clear figure about changes in cells and tissues based on frequencydependent changes, due to their electrical resistances for the applied electrical current. This review explains the physical principle of bioimpedance. And to monitor the progression of radiation induced tissue injury, particularly in radiotherapies. The interaction of radiation with the biological tissues and a prediction for their earlier and later alterations due to exposure are discussed. As well as, an overview for tissue identification by bioelectrical impedance analysis (BIA) is proposed. Bioimpedance analysis "applications and its limitations" in the health care, clinical practice and prognosis of overall survival in cancer patients are discussed.
\end{abstract}

Keywords: Phase Angle (PhA); Body Mass Index (BMI); Fat-Free Mass (FFM); Extracellular Fluid (ECF); Intracellular Fluid (ICF); Estimated Blood Loss (EBL)

\section{Introduction}

Bioelectrical impedance analysis (BIA) is a simple, inexpensive, quick and non-invasive technique for measuring body composition. "Impedance" is a physical variable describing the resistance characteristics of an electrical circuit in the presence of an alternating current between electrodes located in a circumference surrounding the studied object. Thus, it reflects global opposition to the passage of current [1]. Using bioelectrical impedance analysis as a diagnostic tool to examine the electrical characteristics of tissues provides information on a noninvasive and continuous basis, at the patient bedside without need for radiological investigations. Mathematically, the bioelectrical impedance is represented as a complex number comprising a real component (resistance) and an imaginary dimension (reactance) [1]. The electrical impedance (Z) consists of two components, resistance $(\mathrm{R})$ and reactance $(\mathrm{Xc})$. Resistance is a measure of total body water and reactance a measure of BCM. From the determined impedance a number of BIA parameters can be estimated [2]. Body Cell Mass (BCM), consists of all cells that have an effect on metabolism \% BCM in FFM, extra cellular mass (ECM), extracellular water (ECW), fat-free mass (FFM), fat mass (FM), total body water (TBW) [3-6]. The impedance unit is the ohm $(\Omega)$, when this variable is applied to biological tissue we speak of "bioimpedance" [1]. In this context, it is very important to note that the biological tissues have complex electrical impedance. And that is dependent on the frequency of the electrical applied field and tissue cellular structure. Therefore, the electrical impedance of tissue is a function of its structure and it can be used to differentiate normal and cancerous tissues in a variety of organs. Bioimpedance analysis could apply easly and rountely in the arm, trunk, and leg and from wrist to ankle (Figure 1). One of the most important applications of the BIA is its use as a prognostic tool for overall survival, particularly for patients with severe cancers. In this concern, the phase angle ( $\mathrm{PhA})$, is one of the most important indicators for predecting life qualty and overall survival, particularly for cancer patients. Since, the phase angle provides an image about the case of cell membrane function, and $R_{0}$ and $\mathrm{R}_{\infty}$ have been used to predict clinical outcome.

Physically, using of BIA method for characterizing different tissues is to fit data by the Cole equation models, which describe the

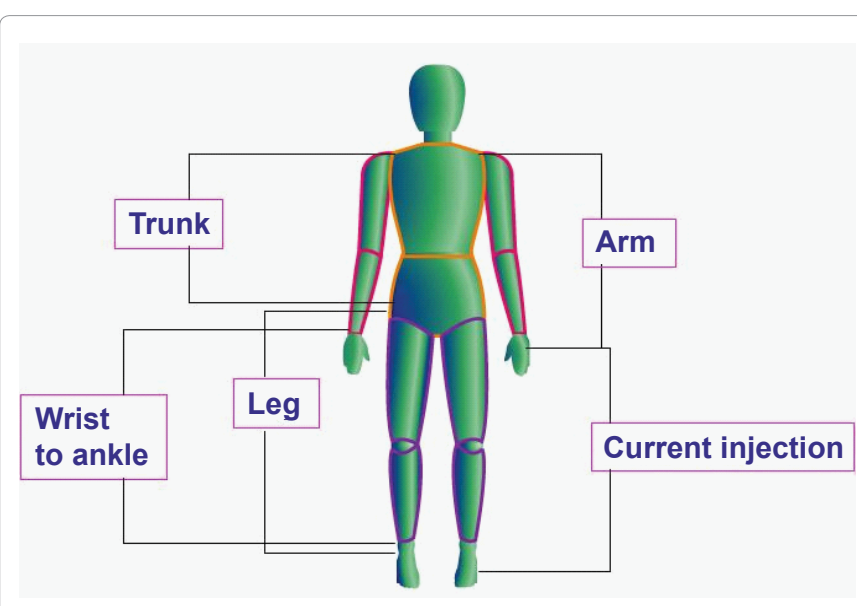

Figure 1: Schematic of human body sites that routenly selected for BIA applications.

behavior of permittivity and conductivity as a function of frequency. The commonly used circuit represents biological tissues activities, in which, the $\mathrm{R}$ of extracellular fluid is arranged in parallel to the second arm of the circuit "which consists of capacitance" and R of intracellular fluid in series. Resistive part (R) and capacitance can all be measured over a range of frequencies (most single frequency BIA analyzers operate at $50-\mathrm{kHz}$ ). At zero (or low) frequency, the current does not penetrate the cell membrane, which acts as an "insulator", and therefore the current passes through the extracellular fluid, which is responsible for the measured $\mathrm{R}$ of the body $\mathrm{R}_{0}$. At infinite frequency (or

*Corresponding author: Tuorkey MJ, Biology Department, Division of Physiology and Medical Biochemistry, Faculty of Science, Damanhour University, Egypt, Fax: 002-045-3368757; E-mail: physio_mj_tuorkey@yahoo.com

Received June 11, 2012; Accepted June 22, 2012; Published June 25, 2012

Citation: Tuorkey MJ (2012) Bioelectrical Impedance as a Diagnostic Factor in the Clinical Practice and Prognostic Factor for Survival in Cancer Patients: Prediction, Accuracy and Reliability. J Biosens Bioelectron 3:121. doi:10.4172/21556210.1000121

Copyright: (c) 2012 Tuorkey MJ, et al. This is an open-access article distributed under the terms of the Creative Commons Attribution License, which permits unrestricted use, distribution, and reproduction in any medium, provided the original author and source are credited. 
very high frequency) the capacitor behaves as a perfect (or near perfect) capacitor, and therefore the total body $\mathrm{R}\left(\mathrm{R}_{\infty}\right)$ reflects the combined of both intracellular and extracellular fluid (Figure 2). The impedance version is shown Cole equation, the corresponding Cole plot in the impedance plane is shown in Figure 2.

$$
Z(\omega)=R_{\infty}+\frac{R_{0}-R_{\infty}}{1+(j \omega \tau)^{\alpha}}
$$

Where, $\mathrm{Z}(\omega)$ is the complex impedance in ohm $(\Omega), \mathrm{R}_{0}$ is the resistive part at zero frequency $(\Omega), \mathrm{R}_{\infty}$ is the resistive part at infinite frequencies $(\Omega)$, $\mathrm{t}$ is a time constant, e.g., the mean relaxation time in a distribution of time constants, and $\alpha(\mathrm{p} / 2)$ is the constant phase angle, $\mathrm{w}$ is the frequency (in $\mathrm{rad} \mathrm{s}^{-1}$ ), the constant 1- $\alpha$ may also be viewed as describing the width of the distribution of time constants.

The present work was designed to provide a rational explanation for the physical principle of bioimpedance and its clinical applications/ limitations. Due to the worldwide spreading for the applications of radiotherapy and radiology, we set this work to provide an imagination for the earlier and later alteration in cellular tissues as a result of radiation exposed.

\section{Radiation: Global Exposure and Safety Standards: An Overview}

The physical properties of the ionizing particles and their interactions with the biological subjects are too comprehensive to be presented here, and readers are referred to an excellent review of Iijima [7]. However, to summarize briefly, energy deposition of the alpha particle is concentrated in a correspondingly small volume near the decay site. Therefore, the radiation dose from alpha emitting radionuclides distributed in the body (for therapeutic purposes or as a result of internal contamination) is highly localized. For instance, cells near the site of radionuclide concentration receive very high doses, whereas more distant cells receive no dose. In contrast, the beta particle is spontaneously decelerated near the nucleus of the target atom, and thus, photons are emitted from the interaction site "braking radiation". A worth note is that the energy of this photons are equal to the difference in the energy of the beta particles before and after the event. In this concern, it is also important to note that low mass, high energy charged particles traveling in high atomic number media may lose energy in a form of photons. And the rate of such loss is termed "the radiative" stopping power. This effect is not often seen for alpha particles and is of limited importance for beta particles and electrons in biologic materials at nuclear medicine energies.

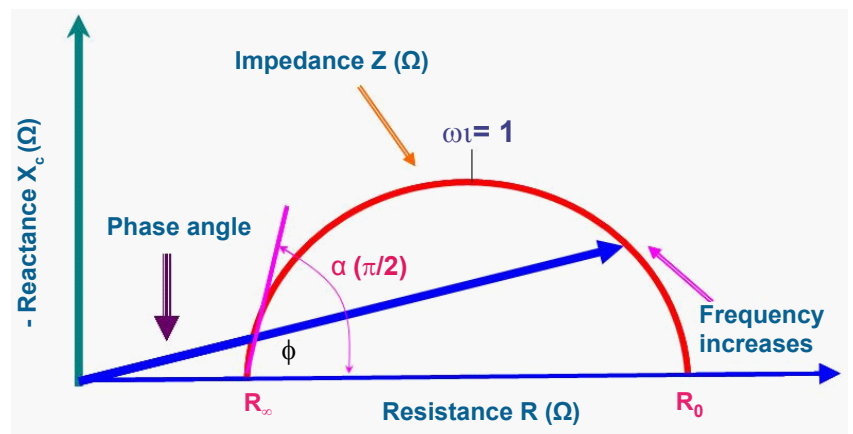

Figure 2: Cole plot in the impedance plane, derivation of the phase angle, resistance $(R)$, reactance $(X c)$, impedance $(Z)$ and the frequency of the applied current.
On the other hand, the global radiation exposure and allowed effective dose are varied depending on the local geology. Radon and thorium are the largest natural sources of exposure, far ahead of cosmic and internal radiation. Data collected over the last 12 years [8] show a medical effective dose per caput of three ranges: higher exposure in Luxemburg, Belgium and Germany (1.8-2.0mSv/year). Low exposure in the UK, the Netherlands and Sweden $(0.4-0.75 \mathrm{mSv} /$ year), intermediate exposure in Norway and Switzerland $(1.1 \mathrm{mSv} / \mathrm{y})$. While western countries showing rather low values of $2.7 \mathrm{mSv} /$ year (UK) or $4 \mathrm{mSv} /$ year (Germany). It is assumed that roughly $5 \%$ of a population exposed to $1 \mathrm{~Sv}$ of effective dose will develop cancer during their lifetime. While such risk is reduced to $2-3 \%$ in the population of western European patients with a peak age of 60-70years, because of the age related lower biological impact of ionizing radiation.

\section{Radiation effects and interactions with the biological system and medical utilization}

In a long-term follow-up study of atomic bomb survivors, data collected for over the last 60 years show that radiation significantly increases the risks of death (22\%), cancer incidence (47\%), death due to leukemia (310\%) at $1 \mathrm{~Gy}$, as well as the incidence of several non-cancer diseases (e.g. thyroid nodules, chronic liver disease and cirrhosis, uterine myoma, and hypertension). Significant effects on maturity (e.g. growth reduction and early menopause) were also observed. Women are much higher section in any population, which expose for the ionizing radiation, due to the worldwide spread for radiologic diagnostic modalities. The exposure to ionizing radiation increases levels of estradiol and other sex hormones, which are acknowledged breast cancer risk factors. A study carried out on cancer-free female A-bomb survivors examined whether ionizing radiation exposure is associated with levels of serum hormones and other markers that may mediate radiation-associated breast cancer risk [9]. This study postulated that at $1 \mathrm{~Gy}$ of radiation dose, a significant increase in the levels of total estradiol (17\%), bioavailable estradiol (21\%) and testosterone $(30.0 \%)$ in postmenopausal women, has been recorded. In contrast, in premenopausal women, the total estradiol, bioavailable estradiol and testosterone were significantly decreased $(-11 \%$ and $-12 \%,-10 \%$, respectively) at $1 \mathrm{~Gy}$.

It is very apt notion that tissues sensitivities for radiation "are varied" depending on their cellular structure. For instance, "slowly dividing" cellular tissues such as the liver, kidney, muscle, bone, lung and connective tissue are radioresistant. Whereas, the "rapidly dividing" cellular tissues such as bone marrow, testis "germinal cells", skin "epithelial cells", gastrointestinal mucosa are radiosensitive [1014]. The extent of the damage in a tissue is also closely related to radiation type, dose, and location. These factors will determine the violence and interval of the cellular depletion. In this sense, the damage effect of radiation may be delayed for months due to "delayed acute reactions". The most important factor for determining the extent of injury in a tissue is its ability to repopulate after radiation damage [15-18]. The dividing stem cells and nondividing functionally mature cells are involved in the process of tissue repopulation. The former will begin to die when they attempt their first or second post-irradiation divisions. While the nondividing differentiated cells, which are relatively unaffected by radiation, will continue to function and to die at their normal rate. However, they will not be so efficiently replaced because of the damage to the stem cell compartment [19]. Tissue injury will not become notable until the number of functional cells falls below a critical level. 
In this context, the permanent and temporal changes-related genes would be very important for understanding the underlying mechanisms of cellular response to radiation [20]. Radiation therapy has been universally approved and widely used as an effective treatment for various cancer types. Amongst cell structures, DNA is much rather sensitive, particularly at high-dose exposure [2,21,22]. Radiation causes DNA double strand breaks, base damage and DNA-protein crosslink to increase genomic instability in the target cancer tissues. Subsequently, it leads to cell cycle arrest, cell death and microvascular destruction. However, radiation effect also may extent to the other healthy cell normal tissue. This effect promotes multiple cytotoxic events, DNA damage and inactivation in the DNA repair system. Upon DNA is damage by ionizing radiation, ultimate signaling activates in the cell take place [23], e.g., cell cycle arrest, DNA damage and mitochondrial disruptions (Figure 3 and 4) [24,25]. In fact, the ability of ionizing radiation to cause the mitotic death of cell and the radio sensitivity of a tissue is directly related to its mitotic activity and inversely proportional to the degree of differentiation of its cells.

Lastly, there has been a universal trend for increasing nuclear medicine utilization for radiologic diagnostic modalities and radio therapeutics. For instance, in Germany, nuclear medicine currently is accounting for around $7 \%$ of the total medical exposure [8]. In some countries the medical contribution to the population dose is in the range of $50 \%$, similar to the USA. Radiation effects whither "stochastic" increasing the probability of cancer induction, and or "deterministic", induces surface damages e.g., skin burns [8]. In fact, there are stringent rules making the vast majority of diagnostic examinations never reach the threshold for this deterministic effect. However, the major problem is that such radiological applications are often require long periods and numerous numbers of spot exposures. The skin is the first and largest outside barrier that protects the internal organs from different

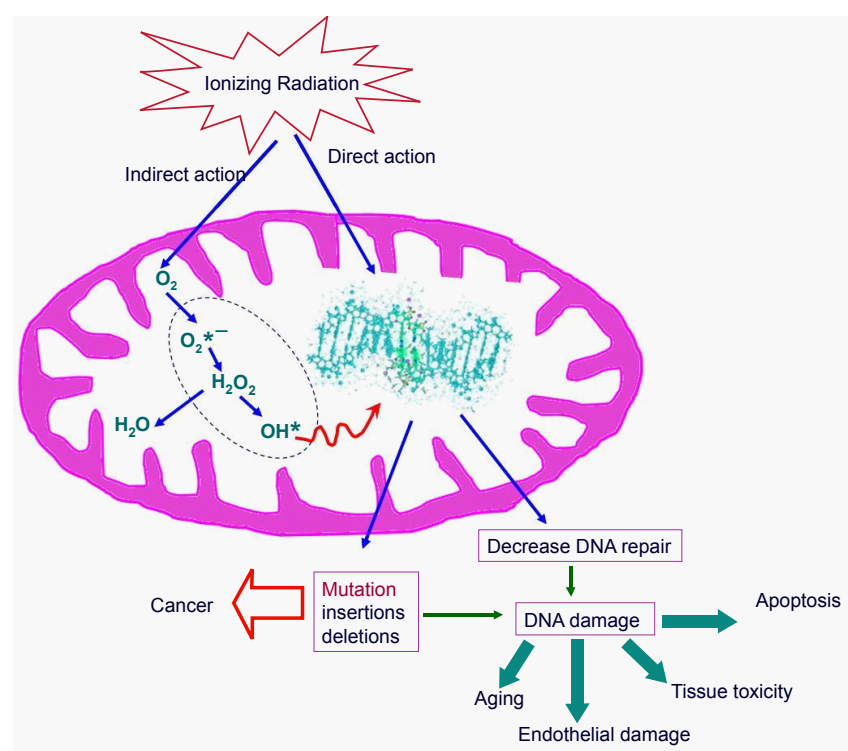

Figure 3: Radiation is interact directly or indirectly with the target, direct effect of radiation on the mitochondria through its interaction directly with DNA leading to deleterious mutations, which in turn, could mediate cancer progression. However, radian could indirectly interact with mitochondrial macromolecules and generate ROS (superoxide anion, hydrogen peroxide, and hydroxyl radicals), which have the ability to damage the mitochondrial DNA, or causing deleterious mutations. This consequently leads to impair in the mitochondrial function or the manifestations of apoptosis, aging, endothelial damage and tissue toxicity without causing a further increase in ROS.

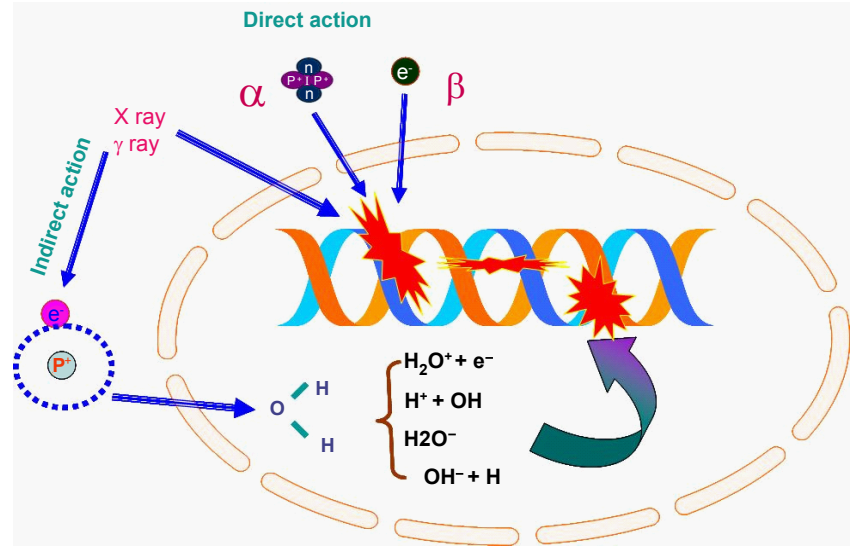

Figure 4: This diagram gives the impression that alpha particle breaks the DNA, the beta particle breaks hydrogen bonds, and X-y rays damage bases when in fact all three types of radiation can cause direct damage. However, heavy charged particles such as $\alpha$ particle have a greater probability of causing direct damage compared to low charged particles such as X-rays which may cause the most of its damage by indirect effects. Radiation mediates DNA mutations by insertions or deletions of DNA sequences, resulting in apoptosis, cancer, and tissue toxicity.

environmental cosmic insults. Energy deposition from particle tracks, when ionizing radiation penetrate skin arises stochastically throughout the exposed mass $[26,27]$. Thus, the local dose may reach the threshold of roughly $3 \mathrm{~Gy}$ for erythema and more severe skin damage [8]. Furthermore, repeated examinations will add up and proportionally increase the risk.

\section{Cell membrane and bioelectrical impedance (functions)}

It is very apt notion that, cells are naturally acquired electrical charges that is due to the process of ions exchanges between the extra and intracellular space. Therefore, one can say that the bioelectric potentials are have critical roles in the body and involved in different regulatory and metabolic processes. Further reinforcing for the biologically importance of bioimpedance, some cells make specialized use of bioelectric potentials and currents for distinctive physiological functions. For instance, in nerve and muscle cells, contraction or relaxation process initiates by which called "electric pulses" due to the action potentials passing along nerve fibres. In fact, cell membrane is consists of an extra-and-intra-cellular membrane, each membrane consists of a lypopylic layer (has an affinity for lipids) and hydrophilic layer (has an affinity for water). Of note, fat is a much poorer conductor of electricity relative to water, thus the changes in body fat and water balance will reflect on tissue impedance. At the low-frequency, the outer lipid membrane could charge completely within the time. At the low-frequency, the outer lipid membrane could charge completely within the time. The accumulation of charges in lipid membrane prevents the current to flow through the extracellular space. With frequency increasing of the applied field, a point is reached at which the time required to charge the intra-and extracellular membranes. These events allowing current to flow through intracellular space, since, the action potential initiation has a threshold behavior. Such application is producing transmembrane voltages above a threshold value initiate action potentials, while those below do not. The degree of injury due to radiation will be depending on the type of the organism and absorbed doses. These injuries will change the physical properties of the exposed tissues. 
Citation: Tuorkey MJ (2012) Bioelectrical Impedance as a Diagnostic Factor in the Clinical Practice and Prognostic Factor for Survival in Cancer Patients: Prediction, Accuracy and Reliability. J Biosens Bioelectron 3:121. doi:10.4172/2155-6210.1000121

\begin{tabular}{|c|c|c|c|c|c|c|c|}
\hline Author & $\begin{array}{l}\text { Subject } \\
\text { group }\end{array}$ & $\mathbf{n}$ & $\begin{array}{l}\text { Refer- } \\
\text { ence }\end{array}$ & BIA parameter & $\begin{array}{c}\text { Method/equation } \\
\text { used }\end{array}$ & Instrument & Comments/appreciation \\
\hline Vilaça et al. [56] & Elderly & 41 & DXA-L & FFM & SF-BIA & RJL & $\begin{array}{l}\text { Mean values for FM and FFM did not differ significantly in } \\
\text { the subject group. The correlation was less strong among } \\
\text { the two subject groups one, suggesting caution when BIA } \\
\text { is to be applied in studies including undernourished older } \\
\text { subjects. Since, variability was high between individuals. }\end{array}$ \\
\hline Lubans et al. [57] & $\begin{array}{l}\text { Year } 9 \text { sec- } \\
\text { ondary school } \\
\text { students }\end{array}$ & 68 & $\% \mathrm{BF}$ & FMM & Cole el al. [58] & SFB7 & $\begin{array}{l}\text { Although the BIA machine produced reliable estimates of } \\
\text { percent body fat, the tests of muscular fitness resulted in } \\
\text { high systematic error. N.P. These measures may require } \\
\text { an extensive familiarization phase before the results can } \\
\text { be considered reliable. }\end{array}$ \\
\hline Jean et al. [59] & ALS & 47 & DXA & FMM & $\mathrm{BIA}$ & RJL & $\begin{array}{l}\text { BIA is valid for use in ALS patients, both for a single exam } \\
\text { measure and for longitudinal monitoring }\end{array}$ \\
\hline Kim et al. [60] & Healthy & 174 & DXA & FFM & BIA & $\begin{array}{l}\text { Eight-electrode } \\
\text { BIA model } \\
\text { DPX-L }\end{array}$ & $\begin{array}{l}\text { Eight-electrode BIA model had small, but systemic, errors } \\
\text { in \%fat and FFM in terms of the predictive accuracy for } \\
\text { individual estimation. The total errors led to an overes- } \\
\text { timation of \%fat in lean individuals among men and an } \\
\text { underestimation of \%fat among obese women. N.P. This } \\
\text { study recommend equations or the correction of these } \\
\text { total errors when the present eightelectrode BIA model. }\end{array}$ \\
\hline Hoyle et al. [61] & Elderly-h. & 22 & ${ }^{2} \mathrm{H}_{2} \mathrm{O}$ & TBW & Bussolotto et al. [62] & RJL & $\begin{array}{l}\text { Total body water estimation by bioelectrical impedance } \\
\text { analysis correlates well with estimation by measurement } \\
\text { of dilution of }{ }^{2} \mathrm{H}_{2} \mathrm{O} \text {. N.P. BIA providing a potentially useful } \\
\text { tool to improve the management of the elderly hypona- } \\
\text { traemic patient. }\end{array}$ \\
\hline Nagai et al. [63] & Healthy & 133 & CT & VFA & $\mathrm{MBI}$ & VFA (IPVFA) & $\begin{array}{l}\text { The excess accumulation of visceral fat area (VFA), which } \\
\text { is associated with metabolic syndrome can easily screen } \\
\text { by MBI } \\
\text { N.P. The method may be a useful tool for primary preven- } \\
\text { tion of metabolic syndrome. }\end{array}$ \\
\hline Medoua et al [64] & HIV & 24 & ${ }^{2} \mathrm{H}_{2} \mathrm{O}$ & TBW & $\begin{array}{l}\text { Paton et al.[65], } \\
\text { Sluys et al.[66], } \\
\text { Kushner and } \\
\text { Schoeller. [67]. Sun } \\
\text { et al. [68], Schoeller } \\
\text { and, Luke. [69], } \\
\text { Kotler et al. [70] }\end{array}$ & Xitron & $\begin{array}{l}\text { The valid published or developed predictive equations } \\
\text { should be cross-validated in large independent samples of } \\
\text { HIV-infected patients. }\end{array}$ \\
\hline Anita et al. [71] & COPD & 41 & DXA & FFM, RMR & $\begin{array}{l}\text { Harris and Benedict. } \\
\text { [72] }\end{array}$ & $\begin{array}{l}\text { DXA } \\
\text { BIA-101 }\end{array}$ & $\begin{array}{l}\text { BIA accurately screened FFM, which is the dominating } \\
\text { factor influencing resting metabolic rate (RMR) }\end{array}$ \\
\hline Jimenez et al. [73] & $\begin{array}{l}\text { morbidly } \\
\text { obese }\end{array}$ & 159 & DXA & FFM & Data input & RJL & $\begin{array}{l}\text { BIA parameters provide accurate estimates of body com- } \\
\text { position in MO subjects }\end{array}$ \\
\hline Zhao et al. [74] & $\begin{array}{l}\text { Pulmonary } \\
\text { ventilation } \\
\text { distribution }\end{array}$ & 50 & DXA & Gl index & LEE & EIT & $\begin{array}{l}\text { The global inhomogeneity index quantifies the gas distri- } \\
\text { bution in the lung with a single number and reveals good } \\
\text { interpatient comparability. }\end{array}$ \\
\hline Reilly et al. [53] & $\begin{array}{l}11-12 \text {-year- } \\
\text { olds, } 84 \text { boys, } \\
92 \text { girls }\end{array}$ & 176 & DXA & $2 \mathrm{H} 2 \mathrm{O}$ & Manufacturer & RJL & $\begin{array}{l}\text { N.P. Errors in estimation of fat mass using BIA and DXA } \\
\text { can be very large, and the direction of error can differ } \\
\text { between the sexes. }\end{array}$ \\
\hline Haroun et al. [52] & $\begin{array}{l}\text { obese and } \\
\text { adolescents }\end{array}$ & 77 & DXA & See reference & Wells et al. [75] & $\begin{array}{l}\mathrm{BIA}, \\
3 \mathrm{C} \text { model }\end{array}$ & $\begin{array}{l}\text { In boys, regression analysis indicated significant differ- } \\
\text { ences in slope }(p<0.001) \text { for } D X A \text {, and both slope }(p< \\
0.001) \text { and intercept }(p<0.001) \text { for BIA. In girls, mean fat } \\
\text { mass from TBW was } 12.1 \mathrm{~kg}(\text { SD } 7.7) \text {; bias for DXA was } \\
+1.2 \mathrm{~kg} \text { (limits of agreement }-1.9 \text { to }+5.1) \text { and bias for BIA } \\
\text { was }-0.2 \mathrm{~kg} \text { (limits of agreement }-5.4 \text { to }+5.1) \text {. }\end{array}$ \\
\hline LaForgia et al. [54] & obese & 18 & DXA & $\begin{array}{l}\text { TBW, FFM, } \\
\% \text { BF }\end{array}$ & Manufacturer & SBIA 4C model & $\begin{array}{l}\text { The BIA estimates of TBW were significantly different } \\
\text { from the criterion measures and intraindividual differences } \\
\text { displayed a large range }(-0.6 \text { to } 3.6 \mathrm{~kg}) \text {. Significant un- } \\
\text { derestimations of TBW via BIA are concerning given that } \\
\text { this is the parameter initially established by this method. } \\
\text { Furthermore, the BIA data resulted in a FFM hydration } \\
\text { value of } 68.5 \% \text { which was significantly }(p<0.001) \text { lower } \\
\text { than the four compartment value of } 72.0 \% \text {. } \\
\text { N.P. The BIA device tested displayed poor individual ac- } \\
\text { curacy for the estimation of body composition compared } \\
\text { with a four compartment criterion method }\end{array}$ \\
\hline
\end{tabular}

DXA: Dual energy X-ray Absortiometry; DXA-L: Dual energy X-ray Absortiometry-Lunar; RJL Systems, Inc, Clinton Twp, MI, USA; Xitron Technologies, San Diego, CA USA; Analycor3, Spengler, France; SF-BIA, Single Frequency BIA; BIS: Bioelectrical Impedance Spectroscopy; BIA: Bioelectrical Impedance Analysis; 3C Model: threeComponent Model; 4C Model: four Compartment Criterion Method; CT: Computed Tomography; MBI: Multifrequeny BI; ALS: Amyotrophic Lateral Sclerosis; Elderly-h: Elderly hyponatraemic patients; COPD: Chronic Obstructive Pulmonary Disease; LEE: Lung area Estimation Method; ${ }^{2} \mathrm{H}_{2} \mathrm{O}$ : Deuterium Oxide; RMR: Resting Metabolic Rate; BMI: Body Mass Index; FFM: Fat-Free Mass; BF: Body Fat; BCM: Body Cell Mass; ECF: Extracellular Fluid; ICF; Intracellular Fluid; EBL: Estimated Blood Loss; TBW: Total Body Water.

Table 1: BIA studies evaluating FFM, BF and BCM in specific groups of subjects. 
Citation: Tuorkey MJ (2012) Bioelectrical Impedance as a Diagnostic Factor in the Clinical Practice and Prognostic Factor for Survival in Cancer Patients: Prediction, Accuracy and Reliability. J Biosens Bioelectron 3:121. doi:10.4172/2155-6210.1000121

Page 5 of 9

\begin{tabular}{|c|c|c|c|c|c|}
\hline Author & Subject group & $\mathbf{n}$ & $\begin{array}{l}\text { Method/BIA pa- } \\
\text { rameter }\end{array}$ & Instrument & Comments/ appreciation \\
\hline Kim et al. & Breast cancer-Rel & 73 & ECF & InBody®720 & $\begin{array}{l}\text { Estimation of ECF and SFBIA before treatment are useful screening tools for } \\
\text { predicting the treatment outcome of patients with lymphedema. }\end{array}$ \\
\hline Vicini et al. [76] & $\begin{array}{l}\text { Upper limb Lym- } \\
\text { phoma }\end{array}$ & 64 & ECF & L-Dex & $\begin{array}{l}\text { L-Dex readings paralleled the extent of surgical interventions and suggest that } \\
\text { they can be used to monitor patients for the early onset of edema. }\end{array}$ \\
\hline Fu et al. [77] & $\begin{array}{l}\text { symptomatic } \\
\text { seroma }\end{array}$ & 130 & arm swelling & BIS & $\begin{array}{l}\text { Patients who developed symptomatic seroma had } 7.78 \text { and } 10.64 \text { times the odds } \\
\text { of developing arm swelling and chest/breast swelling versus those who did not, } \\
\text { respectively }(p<0.001) \text {. }\end{array}$ \\
\hline $\begin{array}{l}\text { Badalato et al. } \\
\text { [46] }\end{array}$ & Prostate tumor & 63 & $\begin{array}{l}\text { FFM, ECW, ICW, } \\
\text { TBW }\end{array}$ & ImpediMed SFB7 & $\begin{array}{l}\text { The correction of metric analysis indicated that BMI correlated with FFM }(p= \\
0.002), \text { FM }(p=0.01) \text {, and \%TBW }(p=0.02) . \% \text { FFM }(p=0.03), \% \text { FM }(p=0.03) \\
\text { and \%TBW }(p=0.04) \text { correlated with \% tumor volume. ICW }(p=0.01) \text { and TBW } \\
(p=0.009) \text { correlated with EBL. BMI }(p=0.04), \% E C W(p=0.04), F M(p=0.05) \text {, FM }(p=0.03) \text { correlated with pathologic tumor stag. }\end{array}$ \\
\hline $\begin{array}{l}\text { Badalato et al. } \\
\text { [46] }\end{array}$ & Breast cancer & 14 & $\mathrm{BF}$ & BIA & $\begin{array}{l}\text { In this study a comparison between ADP, SKF and BIA screening was carried out. } \\
\text { Although ADP and SKF produce similar estimates of BF percentage in all partici- } \\
\text { pants, BIA overestimated BF percentage relative to the other measures. }\end{array}$ \\
\hline Ward et al. [35] & Healthy & 172 & & BIS & $\begin{array}{l}\text { The presence of lymphedema is indicated when the impedance ratio exceeded } \\
1.106 \text { when the nondominant limb is at risk, and } 1.134 \text { when the dominant limb is } \\
\text { at risk compared with the currently used values of } 1.066 \text { and } 1.139 \text {, respectively. } \\
\text { The impedance ratio thresholds for early detection of lymphedema remain suit- } \\
\text { able for clinical use with present day bioimpedance spectroscopy analyzers. }\end{array}$ \\
\hline Ward et al. [35] & Healthy & 18,700 & BMI, FFM & BIA & $\begin{array}{l}\text { This study found some evidence for a possible relationship between higher levels } \\
\text { of physical activity, body size and increased ovarian cancer risk. Ovarian cancer } \\
\text { in relation to BMI was } 1.22(95 \% \mathrm{Cl}: 1.00,1.48 ; \text { p-trend, } 0.06) \text { per } 5 \mathrm{~kg} / \mathrm{m}(2) \\
\text { increment, and for fat mass, } 1.23(95 \% \mathrm{Cl}: 1.01,1.49 ; \text { p-trend, } 0.04) \text { per } 10 \mathrm{~kg} \\
\text { increment. }\end{array}$ \\
\hline Burden et al. [78] & Colorectal cancer & 132 & BMI, \%weight loss & BIA & $\begin{array}{l}\text { BIA screening would be beneficial at an early stage in the care pathway when } \\
\text { they initially enter the secondary care system. }\end{array}$ \\
\hline Liu et al. [79] & Breast cancer. & 200 & $\% \mathrm{BF}$ & BIA & $\begin{array}{l}\mathrm{BMI} \text { and } \mathrm{BF} \% \text { were highly correlated }(\mathrm{r}=0.91 ; \mathrm{p}<0.001) \text {. However, } \mathrm{BMI} \text { exhibited } \\
\text { poor sensitivity for identifying obesity }(47 \%) \text {. The sensitivity of BMI to detect obe- } \\
\text { sity was better in women over age } 60 \text {. The best BMI cutoff for obesity was } 22.3 \\
\mathrm{~kg} / \mathrm{m} 2 \text { with a sensitivity and specificity of } 89 \%(95 \% \mathrm{Cl}=83-94 \%) \text { and } 87 \%(95 \% \\
\mathrm{Cl}=77-93 \%) \text { respectively, and the total accuracy rate improved from } 65 \% \text { to } 89 \% \text {. }\end{array}$ \\
\hline $\begin{array}{l}\text { Czerniec et al. } \\
{[28]}\end{array}$ & Lymphedema & 3318 & $\begin{array}{l}\text { self-report, Perom- } \\
\text { eter, the truncated } \\
\text { cone method }\end{array}$ & BIS & $\begin{array}{l}\text { The physical measurement tools were highly reliable }(\operatorname{ICC}((2,1)): 0.94 \text { to } 1.00) \\
\text { with high concordance }(r(c): 0.89 \text { to } 0.99) \text {. While, Self-report correlated moder- } \\
\text { ately with physical measurements }(r=0.65 \text { to } 0.71) \text { and was moderately reliable } \\
(\operatorname{ICC}((2,1)): 0.70) \text {. }\end{array}$ \\
\hline Wang et al. [80] & Breast cancer & 583 & $\begin{array}{l}\text { Techniques } \\
\text { sensitivities }\end{array}$ & EIS, ultrasound & $\begin{array}{l}\text { Of the } 583 \text { cases, } 143 \text { were diagnosed with breast cancer. The sensitivities } \\
\text { of EIS, ultrasound and the combination method were } 86.7 \%(124 / 143), 72 \% \\
(103 / 143) \text {, and } 93.7 \%(134 / 143) ; \text { the specificities were } 72.9 \%(321 / 440), 82.5 \% \\
(363 / 440) \text {, and } 64.1 \%(282 / 440) \text {, and the relative possibilities of breast cancer } \\
\text { for the positive young women detected by EIS, ultrasound, and the combination } \\
\text { method were } 8.67,5.77 \text {, and } 14.84 \text {, respectively. } \\
\text { N.P. The combination of EIS and ultrasound is an applicable method for early } \\
\text { detection of breast cancer in young women. }\end{array}$ \\
\hline $\begin{array}{l}\text { Halpern-Silveira } \\
\text { et al. [82] }\end{array}$ & cancer & 174 & FFM, BW & BIA & $\begin{array}{l}\text { A significant BW change was found during the treatment in patients submitted to } \\
\text { previous/adjuvant and palliative chemotherapy (weight gain of } 4.15 \% \text { and } 2.23 \% \text {, } \\
\text { respectively, } p=0.05 \text { ) and a significant FFM loss }(7.61 \%, p<0.01) \text { in patients } \\
\text { with severe malnutrition at admission. }\end{array}$ \\
\hline $\begin{array}{l}\text { Wallstrom et al. } \\
\text { [83] }\end{array}$ & $\begin{array}{l}\text { Prostate cancer } \\
\text { risk }\end{array}$ & 10,564 & BMI & BIA & $\begin{array}{l}\text { General adiposity, expressed as BMI or body fat percentage, and prevalent } \\
\text { diabetes were not associated with PCa risk. }\end{array}$ \\
\hline $\begin{array}{l}\text { Isenring et al. } \\
{[84]}\end{array}$ & Oncology & 37 & TBW & BIS & $\begin{array}{l}\text { A cross-sectional, observational study was conducted in } 37 \text { outpatients receiving } \\
\text { radiotherapy ( } 27 \text { males } / 10 \text { females, aged } 68.3 \pm 10.2 \text { years). In this study, TBW } \\
\text { estimated by BIS cannot be directly compared with oncology-specific BIA equa- } \\
\text { tions. } \\
\text { N.P. BIS cannot be used at the group level in outpatients receiving radiotherapy. }\end{array}$ \\
\hline Wu et al. [85] & $\begin{array}{l}\text { Cancer } \\
\text { Healthy }\end{array}$ & $\begin{array}{l}936 \\
840\end{array}$ & ICF, ECF, FM, FFM & BIA & BIA confirmed that cancer patients exhibited lower FM and FFM \\
\hline
\end{tabular}

DXA: Dual energy X-ray Absortiometry; DXA-L: Dual energy X-ray Absortiometry-Lunar; ImpediMed SFB7 Device (San Diego, CA, USA); InBody®720, (Biospace, Korea). BIS: Bioelectrical Impedance Spectroscopy; BIA: Bioelectrical Impedance Analysis; BMI: Body Mass Index; FFM: Fat-Free Mass; BF: Body Fat; BCM: Body Cell Mass; ECF: Extracellular Fluid; ICF; Intracellular Fluid; EBL: Estimated Blood Loss; TBW: Total Body Water; ADP: Air Displacement Plethysmography; SKF: Skinfold Thickness; RARP: Robotic Assisted Radical Prostatectomy; Breast Cancer-Rel: Breast Cancer Related Lymphedema; UL.Lymphedema: Upper Limb Lymphedema.

Table 2: BIA studies evaluating body composition in subjects with cancers.

\section{Tissue Identification and Monitoring}

Any changes in tissue physiology should produce changes in the tissue electrical properties [28]. Based on this phenomenon, BIA analysis has been widely used to identify or monitor the presence of various illnesses or conditions such as body fluid shift, blood flow, cardiac output, and muscular dystrophy [29-32]. Different tissues exhibit different electrical properties, in addition, tissue electrical properties change with respect to tissue status evolution. Thus it is easy to conceive that bioimpedance method can be applied to identify and monitor tissues. The bioimpedance method can be adopted for characterizing different tissues. [30,31]. For instance, the lung tissues 
Citation: Tuorkey MJ (2012) Bioelectrical Impedance as a Diagnostic Factor in the Clinical Practice and Prognostic Factor for Survival in Cancer Patients: Prediction, Accuracy and Reliability. J Biosens Bioelectron 3:121. doi:10.4172/2155-6210.1000121

Page 6 of 9

\begin{tabular}{|c|c|c|c|c|c|c|}
\hline Author & Subject group & $\mathbf{n}$ & BIA-parameter & Instrument & Comments/ appreciation & Limitations \\
\hline $\begin{array}{l}\text { Sanchez-Lara et } \\
\text { al. [86] }\end{array}$ & $\begin{array}{l}\text { Advanced Non-Small- } \\
\text { Cell Lung Cancer }\end{array}$ & 119 & $\mathrm{PhA}$ & RJL & $\begin{array}{l}\text { Patient with Phase angle } \leq 5.8^{\circ} \text { has significant }(p<0.01) \text { poor } \\
\text { survival. }\end{array}$ & $\begin{array}{l}\text { Controlled clini- } \\
\text { cal trial }\end{array}$ \\
\hline $\begin{array}{l}\text { Malecka-Massals- } \\
\text { ka et al. [87] }\end{array}$ & $\begin{array}{l}\text { Head and neck cancer } \\
\text { Healthy volunteers }\end{array}$ & $\begin{array}{l}28 \\
28\end{array}$ & $\mathrm{PhA}$ & $\begin{array}{l}\text { ImpediMed } \\
\text { BIA }\end{array}$ & $\begin{array}{l}\text { Mean vectors of } \mathrm{H} \text { and } \mathrm{NC} \text { group vs. the control group were } \\
\text { characterized by an increased normalized resistance compo- } \\
\text { nent with a reduced reactance component (separate } 95 \% \text { con- } \\
\text { fidence limits, } \mathrm{P}<0.05 \text { ), indicating a decreased ionic conduction } \\
\text { (dehydration) with loss of dielectric mass (cell membranes and } \\
\text { tissue interfaces) of soft tissue. }\end{array}$ & $\begin{array}{l}\text { Controlled clini- } \\
\text { cal trial }\end{array}$ \\
\hline Norman et al. [88] & Cancer & 399 & $\mathrm{PhA}$ & $\mathrm{BIA}$ & $\begin{array}{l}\text { Patients with a phase angle } \leq 5^{\circ} \text { had significantly lower nutri- } \\
\text { tional and functional status, impaired quality of life ( } \mathrm{P} \text { It } 0.0001) \text {, } \\
\text { and increased mortality ( } \mathrm{P} \text { It } 0.001) \text {. }\end{array}$ & $\begin{array}{l}\text { Controlled clini- } \\
\text { cal trial }\end{array}$ \\
\hline Paiva et al. [89] & Cancer & 195 & $\mathrm{PhA}$ & $\mathrm{BIA}$ & $\begin{array}{l}\text { The present study demonstrates that } \mathrm{PA} \text {, used as SPA, is an } \\
\text { independent prognostic indicator. Patients with } \mathrm{PA}<-1.65^{\circ} \text { still } \\
\text { presented a higher mortality rate (RR } 2.35 \mathrm{Cl}: 1.41-3.90 ; p= \\
0.001) \text {. }\end{array}$ & $\begin{array}{l}\text { Prospective } \\
\text { cohort }\end{array}$ \\
\hline $\begin{array}{l}\text { Santarpia et al. } \\
\text { [90] }\end{array}$ & Advanced cancer & 13 & $\mathrm{PhA}$ & BIA & $\begin{array}{l}\text { Phase angle }=0.384, \mathrm{P}=0.024) \text { was found to be strictly related } \\
\text { to survival time and can be therefore considered a prognostic } \\
\text { tool in patients with advanced cancer. }\end{array}$ & $\begin{array}{l}\text { prospective } \\
\text { study: small } \\
\text { sample size }\end{array}$ \\
\hline Davis et al. [91] & Advanced cancer & 50 & $\mathrm{PhA}$ & underwent BIA & $\begin{array}{l}\text { Weight loss was associated with shorter survival. A higher } \\
\text { phase angle (PA) on day } 1 \text { predicted longer survival. Increased } \\
\text { PA during hydration predicted shorter survival: increased } \\
\text { weight during hydration predicted longer survival. An increase } \\
\text { in phase angle during hydration predicted poorer survival and } \\
\text { preexisting intracellular dehydration, cachexia, or poor mem- } \\
\text { brane function. }\end{array}$ & $\begin{array}{l}\text { Controlled clini- } \\
\text { cal trial }\end{array}$ \\
\hline Gupta et al. [92] & advanced NSCLC & 165 & $\mathrm{PhA}$ & $\mathrm{BIA}$ & $\begin{array}{l}\text { Patients with phase angle } \leq 5.3^{\circ} \text { had a median survival of } 7.6 \\
\text { months }(95 \% \mathrm{Cl}: 4.7 \text { to } 9.5 ; \mathrm{n}=81) \text {, while those with }>5.3^{\circ} \\
\text { had } 12.4 \text { months ( } 95 \% \mathrm{Cl}: 10.5 \text { to } 18.7 ; \mathrm{n}=84) ;(\mathrm{p}=0.02) \text {. } \\
\text { Every one degree increase in phase angle was associated with } \\
\text { a relative risk of } 0.79(95 \% \mathrm{Cl}: 0.64 \text { to } 0.97, \mathrm{P}=0.02) \text {. } \\
\text { N.P. Nutritional interventions targeted at improving phase angle } \\
\text { could potentially lead to an improved survival in patients with } \\
\text { advanced non-small cell lung cancer (advanced NSCLC). }\end{array}$ & $\begin{array}{l}\text { Prospective } \\
\text { clinical trial }\end{array}$ \\
\hline
\end{tabular}

Table 3: BIA studies showing an association between Phase Angle (PhA) and survival in cancer patients.

show a 5-fold greater electrical current resistance than the rest of the intrathoracic soft tissues [1]. During the cyclic breathing process, the impedance of the pulmonary tissues changes $5 \%$ in the context of calm breathing, and up to $300 \%$ when inhaling from residual volume to total lung capacity [33]. One of the most attractive applications of bioimpedance characterization is cancer detection [34-39]. Hence, there are vast majority physiological differences in tumor tissues, thus BIA is efficiently applicable method for monitoring and distinguish normal healthy and tumor tissues. For instance tumors have much higher water content in their cells rather normal cells because of cellular necrosis and fenestrated vascularization and that will reflects on the tissue conductivity [19]. The cancerous tissues exhibit sharply different bioelectrical properties as compared with the normal tissues. The higher conductivity of tumors could lead to their selective targeting by radio frequency hyperthermia treatment [40]. In early stages of tumor a disturbance in the cellular water/electrolyte content, cell membrane permeability, and orientation/packing density of cells will occur. These changes and abnormalities will reflect on tissue impedance, which could be detected by using bioimpedance.

\section{Applications of Bia in Health Care, Medical Diagnosis and Quality of Life}

Obesity is a common nutritional problem in both developed and developing countries. In a cross-sectional study, the prevalence of overweightness and obesity using both bioelectrical impedance analysis (BIA) and body mass index (BMI) has been investigated. Mean age of the studied subjects was $21.1 \pm 1.7$ years. A close correlation $(0.883$ and 0.908 in males and females, respectively) for BMI and obesity has been confirmed [41]. Table 1 is a summary of BIA studies evaluating body composition including FFM, BF and BCM. On the other hand, in a prospective study the usefulness of bioimpedance measurement have been investigated for predicting the treatment outcome in breast cancer related lymphedema (BCRL) patients [42]. In this study, the ratio of extracellular fluid (ECF) volume has been investigated by using bioelectrical impedance spectroscopy (BIS), and single frequency bioimpedance analysis (SFBIA) at a $5 \mathrm{kHz}$ frequency before treatment. They also investigated whether there is correlation between ECF ratio and SFBIA ratio with the change of arm circumference. The study concluded that ECF volume measurements and SFBIA before treatment are useful tools for predicting the outcome of patients with lymphedema. Additionally, ECF volume measure can be used as a screening tool for predicting treatment outcome of BCRL patients. Table 2, summarized BIA studies evaluating body composition in subjects with cancers. There are lots of studies involved phase angle as a reliable predictive factor for quality of life and overall survival, particularly for cancer patients (Table 3 ).

\section{Physiological Parameters Affecting Bioelectrical Im- pedance Accuracy}

Although the fact that an increased conductivity may be used to identify the presence of tumors [43,44], there are lots of limitations for BIA metric analysis due to the complication and variation in the biological system [45]. Their important review by author Damijan et al. [19] discussed efficiently lots of problems in the biological concern. Relative to water, fat is a much poorer conductor of electricity, thus the changes in body fat and water balance will reflect on tissue impedance. Cell and tissue death also cause many irreversible changes including viscosity of the extra/intracellular fluids [46]. And promote changes in the mobility and distribution of ions which have the ability to transport the current. In the lived physiological system, if the blood flow is 
Citation: Tuorkey MJ (2012) Bioelectrical Impedance as a Diagnostic Factor in the Clinical Practice and Prognostic Factor for Survival in Cancer Patients: Prediction, Accuracy and Reliability. J Biosens Bioelectron 3:121. doi:10.4172/2155-6210.1000121

interrupted, metabolism could continue in an anaerobic manner. That in turn, leads to an increase in the level of the extracellular fluid due to the osmotic pressure. Therefore, BIA when applied in such conditions a false increase in the tissue impedance. Even, the brief decrease in the blood flow has an impact and could change tissue resistivity. The respective figures are not absolute and can vary according to the conditions of the environment or medium (e g. temperature). A temperature increase is associated with a decrease in impedance [1], due to the prominent increase in ions mobility [47-49] that "transport the current", and decrease viscosity of the extracellular fluid. A general increase of about $2 \%$ occurs in the conductivity of tissue [50] in the frequency range below $1 \mathrm{GHz}$, up to a temperature of about $40^{\circ} \mathrm{C}$. Above that point, the cell membrane begins to deteriorate and allows the cytosol to leak into the extracellular space. Nevertheless, the rapid increase of conductivity with temperature was suggested to be used to monitor the progress of hyperthermia treatment [51].

\section{Conclusion}

BIA works well in healthy subjects and chronic diseases with a validated BIA equation that is appropriate with regard to age, sex and race. The metric measurements includes: body mass index, fat-free mass, body fat, body cell mass, extracellular fluid, intracellular fluid, blood loss, and total body water. Due to interindividual differences in growth velocity and puberty related changes in children making Bioimpedance metric analysis interpretation much difficult. For instance, errors in estimation of fat mass using Bioimpedance analysis and DXA can be very large, and the direction of error can differ between the sexes in children [52,53]. Furthermore, The Bioimpedance analysis device tested displayed poor individual accuracy for the estimation of body composition compared with a four compartment criterion method [54]. In this sense, it is very important to note that the use of segmental Bioimpedance analysis also requires further validation at increased temperature, edema and abnormal hydration. Thus, Bioimpedance analysis should be interpreted with caution until further validation has proven for Bioimpedance analysis algorithm to be accurate in such conditions. The potential sources of errors for Bioimpedance analysis in some specific subjects may be due to increased bone mass of limbs and changes in skin thickness and hydration, which might influence the extension of the tissues electrical characteristics. The eight-electrode BIA model had also small, but systemic, errors in \%fat and fat-free mass. These errors led to an overestimation of \% fat in lean individuals among men and an underestimation of \%fat among obese women. Therefore, the general use of eight electrode BIA model should be interpreted with caution, until the valid or recommend equations or the correction of these total errors is resolved. Caution is recommended when using BIA as the body composition method for breast cancer survivors who have completed treatment but are still undergoing adjuvant hormonal therapy [46]. The use of more than one method should be used to derive more physiologically reliable information, which could be potentially useful for providing validation to avoid such errors. Lastly, the clinical benefit of BIA can be further enhanced by combining it with bioelectrical impedance vector analysis (BIVA) [55].

\section{References}

1. Riera J, Riu PJ, Casan P, Masclans JR (2011) Electrical impedance tomography in acute lung injury. Med Intensiva 35: 509-517.

2. Asadullina NR, Usacheva AM, Gudkov SV (2012) Protection of mice against X-ray injuries by the post-irradiation administration of inosine-5'monophosphate. J Radiat Res 53: 211-216.

3. Liston A, Bayford R, Holder D (2012) A cable theory based biophysical model of resistance change in crab peripheral nerve and human cerebral cortex during neuronal depolarisation: implications for electrical impedance tomography of fast neural activity in the brain. Med Biol Eng Comput 50: 425-437.

4. Chatziioannidis I, Samaras T, Nikolaidis N (2011) Electrical Impedance Tomography: a new study method for neonatal Respiratory Distress Syndrome? Hippokratia 15: 211-215.

5. Martins T, Camargo E, Lima R, Amato M, Tsuzuki M (2012) Image Reconstruction Using Interval Simulated Annealing in Electrical Impedance Tomography. IEEE Trans Biomed Eng .

6. Raneta O, Ondruš D, Bella V (2012) Utilisation of electrical impedance tomography in breast cancer diagnosis. Klin Onkol 25: 36-41.

7. Simpkin DJ (1999) Radiation interactions and internal dosimetry in nuclear medicine. Radiographics 19: 155-167.

8. European Society of Radiology (ESR) (2011) White paper on radiation protection by the European Society of Radiology. Insights Imaging 2: 357-362.

9. Grant EJ, Neriishi K, Cologne J, Eguchi H, Hayashi T, et al. (2011) Associations of ionizing radiation and breast cancer-related serum hormone and growth factor levels in cancer-free female A-bomb survivors. Radiat Res 176: 678-687.

10. Ritz B, Morgenstern H, Crawford-Brown D, Young B (2000) The effects of internal radiation exposure on cancer mortality in nuclear workers at Rocketdyne/Atomics International. Environ Health Perspect 108: 743-751.

11. Levi F (1999) Cancer prevention: epidemiology and perspectives. Eur J Cancer 35: 1046-1058.

12. Richardson DB, Wing S (1999) Radiation and mortality of workers at Oak Ridge National Laboratory: positive associations for doses received at older ages. Environ Health Perspect 107: 649-656.

13. Ferrari L, Menezes G, Rosai J (2011) Radiation-induced atypia of vestigial thymic epithelium. Report of two cases of yet another pseudoneoplastic condition. Histopathology 59: 1023-1025.

14. Sun T, Wang Z, Wang J, Wu Y, Li D, et al. (2011) Outcome of radical resection and postoperative radiotherapy for thyroid carcinoma showing thymus-like differentiation. World J Surg 35: 1840-1846.

15. Moon Y (2011) Mucosal Injuries due to Ribosome-Inactivating Stress and the Compensatory Responses of the Intestinal Epithelial Barrier. Toxins (Basel) 3: 1263-1277.

16. Madas BG, Balásházy I (2011) Mutation induction by inhaled radon progeny modeled at the tissue level. Radiat Environ Biophys 50: 553-570.

17. Raabe OG (2011) Toward improved ionizing radiation safety standards. Health Phys 101: 84-93.

18. Yen PN, Yang CC, Chang PW, Hwang JS, Lee HC, et al. (2011) Perception of quality of life of a cohort population years after relocation from previous low-dose radiation exposure in Co-60 contaminated buildings in Taiwan. Int $J$ Radiat Biol 87: 453-460.

19. Damijan M, Natasa P, Francis XH (2006) Electric properties of biological tissues. Wiley Encyclopedia of Biomedical Engineering.

20. Kim KH, Yoo HY, Joo KM, Jung Y, Jin J, et al. (2011) Time-course analysis of DNA damage response-related genes after in vitro radiation in $\mathrm{H} 460$ and H1229 lung cancer cell lines. Exp Mol Med 43: 419-426.

21. Keller A, Bald I, Rotaru A, Cauët E, Gothelf KV, et al. (2012) Probing electroninduced bond cleavage at the single-molecule level using DNA origam templates. ACS Nano 6: 4392-4399.

22. Beck M, Moreels $M$, Jacquet $P$, Van Oostveldt $P$, De Vos WH, et al. (2012) X-irradiation induces cell death in fetal fibroblasts. Int J Mol Med 30: 114-118.

23. Falck J, Coates J, Jackson SP (2005) Conserved modes of recruitment of ATM, ATR and DNA-PKcs to sites of DNA damage. Nature 434: 605-611.

24. Durocher D, Jackson SP (2001) DNA-PK, ATM and ATR as sensors of DNA damage: variations on a theme? Curr Opin Cell Biol 13: 225-231.

25. Stracker TH, Usui T, Petrini JH (2009) Taking the time to make important decisions: the checkpoint effector kinases Chk1 and Chk2 and the DNA damage response. DNA Repair (Amst) 8: 1047-1054.

26. Thomas SJ, Cowley IR (2012) A comparison of four indices for combining distance and dose differences. Int J Radiat Oncol Biol Phys 82: e717-e723.

27. Grégoire V, Mackie TR (2011) State of the art on dose prescription, reporting 
Citation: Tuorkey MJ (2012) Bioelectrical Impedance as a Diagnostic Factor in the Clinical Practice and Prognostic Factor for Survival in Cancer Patients: Prediction, Accuracy and Reliability. J Biosens Bioelectron 3:121. doi:10.4172/2155-6210.1000121

and recording in Intensity-Modulated Radiation Therapy (ICRU report No. 83) Cancer Radiother 15: 555-559.

28. Czerniec SA, Ward LC, Refshauge KM, Beith J, Lee MJ, et al. (2010) Assessment of breast cancer-related arm lymphedema--comparison of physical measurement methods and self-report. Cancer Invest 28: 54-62.

29. San-Frutos L, Engels V, Zapardiel I, Perez-Medina T, Almagro-Martinez J, et al. (2011) Hemodynamic changes during pregnancy and postpartum: a prospective study using thoracic electrical bioimpedance. J Matern Fetal Neonatal Med 24: 1333-1340.

30. Kalvoy H, Martinsen OG, Grimnes S (2008) Determination of tissue type surrounding a needle tip by electrical bioimpedance. Conf Proc IEEE Eng Med Biol Soc 2008: 2285-2286.

31. Rundle A, Richards C, Neugut Al (2009) Body composition, abdominal fat distribution, and prostate-specific antigen test results. Cancer Epidemiol Biomarkers Prev 18: 331-336.

32. Noshiro M, Morimoto T, Nagao H, Matsuda H (1993) Electrical impedance in the lower limbs of patients with Duchenne muscular dystrophy: a preliminary study. Med Biol Eng Comput 31: 97-102.

33. Harris ND, Suggett AJ, Barber DC, Brown BH (1987) Applications of applied potential tomography (APT) in respiratory medicine. Clin Phys Physiol Meas 8: $155-165$.

34. do Amaral CE, Lopes HS, Arruda LV, Hara MS, Gonçalves AJ, et al. (2011) Design of a complex bioimpedance spectrometer using DFT and undersampling for neural networks diagnostics. Med Eng Phys 33: 356-361.

35. Ward LC, Dylke E, Czerniec S, Isenring E, Kilbreath SL (2011) Confirmation of the reference impedance ratios used for assessment of breast cancer-related lymphedema by bioelectrical impedance spectroscopy. Lymphat Res Biol 9: 47-51.

36. Cagini L, Capozzi R, Tassi V, Savignani C, Quintaliani G, et al. (2011) Fluid and electrolyte balance after major thoracic surgery by bioimpedance and endocrine evaluation. Eur J Cardiothorac Surg 40: e71-e76.

37. Crawford GB, Robinson JA, Hunt RW, Piller NB, Esterman A (2009) Estimating survival in patients with cancer receiving palliative care: is analysis of body composition using bioimpedance helpful? J Palliat Med 12: 1009-1014.

38. Halaska M, Strnad P, Chod J, Malá I, Nováková M, et al. (2007) [Detection of postoperative lymphoedema in patients with breast cancer]. Ceska Gynekol 72: $299-304$

39. Gonzalez-Correa CA, Brown BH, Smallwood RH, Stephenson TJ, Stoddard CJ, et al. (2003) Low frequency electrical bioimpedance for the detection of inflammation and dysplasia in Barrett's oesophagus. Physiol Meas 24: 291296.

40. Joines WT, Zhang Y, Li C, Jirtle RL (1994) The measured electrical properties of normal and malignant human tissues from 50 to $900 \mathrm{MHz}$. Med Phys 21: $547-550$

41. Heydari ST, Ayatollahi SM, Zare N (2011) Diagnostic Value of Bioelectrica Impedance Analysis versus Body Mass Index for Detection of Obesity among Students. Asian J Sports Med 2: 68-74.

42. Kim L, Jeon JY, Sung IY, Jeong SY, Do JH, et al. (2011) Prediction of treatment outcome with bioimpedance measurements in breast cancer related lymphedema patients. Ann Rehabil Med 35: 687-693.

43. Haemmerich D, Wood BJ (2006) Hepatic radiofrequency ablation at low frequencies preferentially heats tumour tissue. Int J Hyperthermia 22: 563-574.

44. Haemmerich D, Staelin ST, Tsai JZ, Tungjitkusolmun S, Mahvi DM, et al. (2003) In vivo electrical conductivity of hepatic tumours. Physiol Meas 24: 251-260.

45. Blad B, Wendel P, Jönsson M, Lindström K (1999) An electrical impedance index to distinguish between normal and cancerous tissues. J Med Eng Technol 23: $57-62$.

46. Badalato GM, Wosnitzer MS, Truesdale MD, Sandri M, Ko WJ, et al. (2011) Evaluation of preoperative bioimpedance spectroscopy quantification of body composition on predicting postoperative outcomes following robotic assisted radical prostatectomy (RARP). Can J Urol 18: 6031-6036.

47. COLE KS (1949) Some physical aspects of bioelectric phenomena. Proc Natl Acad Sci U S A 35: 558-566.

48. Nopp P, Rapp E, Pfützner H, Nakesch H, Ruhsam C (1993) Dielectric properties of lung tissue as a function of air content. Phys Med Biol 38: 699-716.

49. Kim Y, Webster JG, Tompkins WJ (1983) Electrical impedance imaging of the thorax. J Microw Power 18: 245-257.

50. Foster KR, Schwan HP (1989) Dielectric properties of tissues and biological materials: a critical review. Crit Rev Biomed Eng 17: 25-104.

51. Haemmerich D, Ozkan R, Tungjitkusolmun S, Tsai JZ, Mahvi DM, et al. (2002) Changes in electrical resistivity of swine liver after occlusion and postmortem. Med Biol Eng Comput 40: 29-33.

52. Haroun D, Croker H, Viner RM, Williams JE, Darch TS, et al. (2009) Validation of BIA in obese children and adolescents and re-evaluation in a longitudinal study. Obesity (Silver Spring) 17: 2245-2250.

53. Reilly JJ, Gerasimidis K, Paparacleous N, Sherriff A, Carmichael A, et al. (2010) Validation of dual-energy $\mathrm{x}$-ray absorptiometry and foot-foot impedance against deuterium dilution measures of fatness in children. Int J Pediatr Obes 5: 111 115

54. LaForgia J, Gunn S, Withers RT (2008) Body composition: validity of segmental bioelectrical impedance analysis. Asia Pac J Clin Nutr 17: 586-591.

55. Walter-Kroker A, Kroker A, Mattiucci-Guehlke M, Glaab T (2011) A practical guide to bioelectrical impedance analysis using the example of chronic obstructive pulmonary disease. Nutr J 10: 35.

56. Vilaça KH, Paula FJ, Ferriolli E, Lima NK, Marchini JS, et al. (2011) Body composition assessment of undernourished older subjects by dual-energy $\mathrm{x}$-ray absorptiometry and bioelectric impedance analysis. J Nutr Health Aging15: 439-443

57. Lubans DR, Morgan P, Callister R, Plotnikoff RC, Eather N, et al. (2011) Testretest reliability of a battery of field-based health-related fitness measures for adolescents. J Sports Sci 29: 685-693.

58. Cole TJ, Bellizzi MC, Flegal KM, Dietz WH (2000) Establishing a standard definition for child overweight and obesity worldwide: international survey. BM 320: $1240-1243$

59. Desport JC, Preux PM, Bouteloup-Demange $C$, Clavelou $P$, Beaufrère $B$ et al. (2003) Validation of bioelectrical impedance analysis in patients with amyotrophic lateral sclerosis. Am J Clin Nutr 77: 1179-1185.

60. Kim H, Kim CH, Kim DW, Park M, Park HS, et al. (2011) External crossvalidation of bioelectrical impedance analysis for the assessment of body composition in Korean adults. Nutr Res Pract 5: 246-252.

61. Hoyle GE, Chua M, Soiza RL (2011) Volaemic assessment of the elderly hyponatraemic patient: reliability of clinical assessment and validation of bioelectrical impedance analysis. QJM 104: 35-39.

62. Bussolotto M, Ceccon A, Sergi G, Giantin V, Benincà P, et al. (1999) Assessment of body composition in elderly: accuracy of bioelectrical impedance analysis. Gerontology 45: 39-43.

63. Nagai M, Komiya H, Mori Y, Ohta T, Kasahara Y, et al. (2010) Estimating visceral fat area by multifrequency bioelectrical impedance. Diabetes Care 33 : 1077-1079.

64. Medoua GN, Ndzana Abomo AC, Essa'a VJ, Sobgui CM, Messomo MT, et al (2008) Validity of impedance-based equations for the prediction of total body water as measured by deuterium dilution in Cameroonian HIV-infected patients treated with antiretroviral treatment. Clin Nutr 27: 881-888.

65. Paton NI, Elia M, Jennings G, Ward LC, Griffin GE (1998) Bioelectrica impedance analysis in human immunodeficiency virus-infected patients: comparison of single frequency with multifrequency, spectroscopy, and other novel approaches. Nutrition 14: 658-666.

66. Sluys TE, van der Ende ME, Swart GR, van den Berg JW, Wilson JH (1993) Body composition in patients with acquired immunodeficiency syndrome: a validation study of bioelectric impedance analysis. JPEN J Parenter Enteral Nutr 17: 404-406.

67. Kushner RF, Schoeller DA (1986) Estimation of total body water by bioelectrica impedance analysis. Am J Clin Nutr 44: 417-424.

68. Sun SS, Chumlea WC, Heymsfield SB, Lukaski HC, Schoeller D, et al. (2003) Development of bioelectrical impedance analysis prediction equations for body composition with the use of a multicomponent model for use in epidemiologic surveys. Am J Clin Nutr 77: 331-340.

69. Schoeller DA, Luke A (2000) Bioelectrical impedance analysis prediction 
Citation: Tuorkey MJ (2012) Bioelectrical Impedance as a Diagnostic Factor in the Clinical Practice and Prognostic Factor for Survival in Cancer Patients: Prediction, Accuracy and Reliability. J Biosens Bioelectron 3:121. doi:10.4172/2155-6210.1000121

equations differ between African Americans and Caucasians, but it is not clear why. Ann N Y Acad Sci 904: 225-226.

70. Kotler DP, Burastero S, Wang J, Pierson RN Jr (1996) Prediction of body cell mass, fat-free mass, and total body water with bioelectrical impedance analysis: effects of race, sex, and disease. Am J Clin Nutr 64: 489S-497S.

71. Nordenson A, Grönberg AM, Hulthén L, Larsson S, Slinde F (2010) A validated disease specific prediction equation for resting metabolic rate in underweight patients with COPD. Int J Chron Obstruct Pulmon Dis 5: 271-276.

72. Harris JA, Benedict FG (1918) A Biometric Study of Human Basal Metabolism. Proc Natl Acad Sci U S A 4: 370-373.

73. Jiménez A, Omaña W, Flores L, Coves MJ, Bellido D, et al. (2012) Prediction of whole-body and segmental body composition by bioelectrical impedance in morbidly obese subjects. Obes Surg 22: 587-593.

74. Zhao Z, Möller K, Steinmann D, Frerichs I, Guttmann J (2009) Evaluation of an electrical impedance tomography-based Global Inhomogeneity Index for pulmonary ventilation distribution. Intensive Care Med 35: 1900-1906.

75. Wells JC, Fuller NJ, Wright A, Fewtrell MS, Cole TJ (2003) Evaluation of air-displacement plethysmography in children aged 5-7 years using a threecomponent model of body composition. Br J Nutr 90: 699-707.

76. Vicini F, Shah C, Lyden M, Whitworth P (2012) Bioelectrical impedance for detecting and monitoring patients for the development of upper limb lymphedema in the clinic. Clin Breast Cancer 12: 133-137.

77. Fu MR, Guth AA, Cleland CM, Lima ED, Kayal M, et al. (2011) The effects of symptomatic seroma on lymphedema symptoms following breast cancer treatment. Lymphology 44: 134-143.

78. Burden ST, Hill J, Shaffer JL, Todd C (2010) Nutritional status of preoperative colorectal cancer patients. J Hum Nutr Diet 23: 402-407.

79. Liu LN, Miaskowski C, Wang JS, Chen SC, Chen ML (2010) Accuracy of body mass index to determine obesity in women with breast cancer: an observational study of Taiwanese sample. Int J Nurs Stud 47: 994-1000.

80. Wang T, Wang K, Yao Q, Chen JH, Ling R, et al. (2010) Prospective study on combination of electrical impedance scanning and ultrasound in estimating risk of development of breast cancer in young women. Cancer Invest 28: 295-303.

81. Crawford GB, Robinson JA, Hunt RW, Piller NB, Esterman A (2009) Estimating survival in patients with cancer receiving palliative care: is analysis of body composition using bioimpedance helpful? J Palliat Med 12: 1009-1014.
82. Halpern-Silveira D, Susin LR, Borges LR, Paiva SI, Assunção MC et al. (2010) Body weight and fat-free mass changes in a cohort of patients receiving chemotherapy. Support Care Cancer 18: 617-625.

83. Wallström P, Bjartell A, Gullberg B, Olsson H, Wirfält E (2009) A prospective Swedish study on body size, body composition, diabetes, and prostate cancer risk. Br J Cancer 100: 1799-1805.

84. Isenring E, Colombo M, Cross G, Kellett E, Swaney L (2009) Estimation of total body water from bioelectrical impedance spectroscopy in oncology outpatients receiving radiotherapy and agreement with three prediction equations. J Hum Nutr Diet 22: 50-54.

85. Wu GH, Cao DX, Wei J, Quan YJ, Wu ZH (2008) [Assessment of energy expenditure and body composition in cancer patients]. Zhonghua Wai Ke Za Zhi 46: 1906-1909.

86. Sánchez-Lara K, Turcott JG, Juárez E, Guevara P, Núñez-Valencia C, et al. (2012) Association of nutrition parameters including bioelectrical impedance and systemic inflammatory response with quality of life and prognosis in patients with advanced non-small-cell lung cancer: a prospective study. Nutr Cancer 64: 526-534.

87. Malecka-Massalska T, Smolen A, Zubrzycki J, Lupa-Zatwarnicka K, Morshed $\mathrm{K}$ (2012) Bioimpedance vector pattern in head and neck squamous cell carcinoma. J Physiol Pharmacol 63: 101-104.

88. Norman K, Stobäus N, Zocher D, Bosy-Westphal A, Szramek A, et al. (2010) Cutoff percentiles of bioelectrical phase angle predict functionality, quality of life, and mortality in patients with cancer. Am J Clin Nutr 92: 612-619.

89. Paiva SI, Borges LR, Halpern-Silveira D, Assunção MC, Barros AJ, et al. (2010) Standardized phase angle from bioelectrical impedance analysis as prognostic factor for survival in patients with cancer. Support Care Cancer 19: 187-192.

90. Santarpia L, Marra M, Montagnese C, Alfonsi L, Pasanisi F, et al. (2009) Prognostic significance of bioelectrical impedance phase angle in advanced cancer: preliminary observations. Nutrition 25: 930-931.

91. Davis MP, Yavuzsen T, Khoshknabi D, Kirkova J, Walsh D, et al. (2009) Bioelectrical impedance phase angle changes during hydration and prognosis in advanced cancer. Am J Hosp Palliat Care 26: 180-187.

92. Gupta D, Lammersfeld CA, Vashi PG, King J, Dahlk SL, et al. (2009) Bioelectrica impedance phase angle in clinical practice: implications for prognosis in stage IIIB and IV non-small cell lung cancer. BMC Cancer 9: 37. 